\title{
Literary Psychology and Style
}

\author{
Gulnora Khakimova Abdumalikovna
}

\begin{abstract}
The central issues of discussion are the problems of style and literary psychology. The style of the writers differs in the selection of psychological analysis means. The specification of the article is to analyze and exemplify specific cases of literary psychology of authors in the two works of literature.
\end{abstract}

Keywords: psychological style, motif, dynamic and typological principles of psychological analysis, style, psychological analysis, monologues, hallucinations and psychological parallelisms, spiritual degradation.

\section{INTRODUCTION}

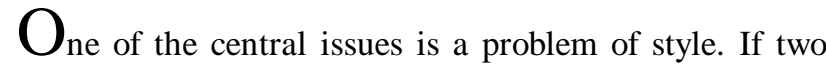
writers create a work using true-life material, two different works are brought into life. Style is not only linked to the way the image is, but also to the writer's attitude toward life and has its effect in his ability to choose the true-life material and his heroes to the literary idea, appointment of the language and expression means.

\section{LITERATURE REVIEW}

ThisAny professional writer is primarily a psychologist. However, as each writer is interested in the various aspects of the human spiritual world, there are different styles and means of using it. For instance, analysing psychology in the works of L. Tolstoy N.G. Chernyshevsky wrote: "Psychological analysis may have different directions: one writer can be more interested in the attributes of the characters, and another can be interested in the effects of social relationships and domestic conflicts on characters; the third one can be interested in the relationship between perceptions and activities, and the fourth one can be in the analysis of passions. Count Tolstoy, most of all, was interested in the psychic process itself, its forms, canons, posturizing with a more accurate term, in heart dialectics".

Narzulla Shodiev, a psychologist who carried out analysis of Abdulla Khakhhor's works, points out that psychological analysis has three principles identified by academician $\mathrm{M}$. Khrapchenko. These are: dynamic principle, typological principle and analytical principles. On the basis of his observations N. Shodiev came to the conclusion that Abdulla Kakhhor had used all these principles.

Correspondingly, it can be said that Jack London is completely attracted to all processes of the hero's spiritual world, progressions and degradation. A lot of methods utilized by the author to reveal the hero's spiritual world are

Revised Manuscript Received on October 15, 2019.

* Correspondence Author

Gulnora Khakimova Abdumalikovna *, A teacher of Arts faculty, Bukhara State University, Uzbekistan, gulnora2404@ mail.ru. monologues, hallucinations and psychological parallelisms. The writer thoroughly depicts the worldview, the world of deliberations, emotions of Martin Eden in a particular moment. In Martin's monologue, we can be aware of his views on life and art. At the same time, these monologues are the sharpest clashes of Martin's outlook, which progresses with the outer atmosphere. In Martin's monologues the aesthetic principles set forth in literary-critical articles of Jack London are reflected.

Jack London made use of - is a psychological parallelism. Parallelism is an literary style characterized by the vivid representation of a particular feature of one of the two phenomena by putting them together. Parallelisms are more common in oral folk songs. Likewise, in literature there are distinguished syntactic parallelism, lexical-morphological parallelism, psychological parallelism, composition parallelism.

The psychological parallelism associated with Cheese-Face is based upon confliction.In the novel, literary interiors are also seen as a psychological parallelism based on confliction. Jack London describes Martin's rented apartment as: "In his own small room Martin lived, slept, studied, wrote, and kept house. Before the one window, looking out on the tiny front porch, was the kitchen table that served as desk, library, and typewriting stand. The bed, against the rear wall, occupied two-thirds of the total space of the room. The table was flanked on one side by a gaudy bureau, manufactured for profit and not for service, the thin veneer of which was shed day by day. This bureau stood in the corner, and in the opposite corner, on the table's other flank, was the kitchen - the oil-stove on a dry-goods box, inside of which were dishes and cooking utensils, a shelf on the wall for provisions, and a bucket of water on the floor. Martin had to carry his water from the kitchen sink, there being no tap in his room. On days when there was much steam to his cooking, the harvest of veneer from the bureau was unusually generous. Over the bed, hoisted by a tackle to the ceiling, was his bicycle. At first he had tried to keep it in the basement; but the tribe of Silva, loosening the bearings and puncturing the tires, had driven him out. Next he attempted the tiny front porch, until a howling south-eastern drenched the wheel a night-long. Then he had retreated with it to his room and slung it aloft" (177). This narrow and airless cell was opposed to Martin's infinite imagination and awesome fantasy. In this very cell, in which Martin had to "skilfully advance forward" otherwise, hitting the staff around was inevitable, mindfully he could travel around different places and epochs, create his works, which were examples of great deliberation and art.

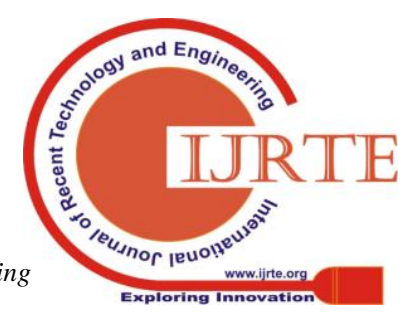


Martin's apartment, which was integrally pictured in the preliminary pages of the novel, was in contravention of the house where the Morse lived. If in Martin's, it was: “To go from the door to the head of the bed was a zigzag course that he was never quite able to accomplish in the dark without collision" (177), in the Morse's, between a grand piano and a centre-table piled high with books was space for a half a dozen to walk abreast (2). While due to the narrowness of the room, Martin cooked sitting and reached anything from his seat, in the Morse's, one first entered the "big hall", walked through large rooms and went to a separate dining room for having a meal.Nonetheless, as the work progresses, it becomes conspicuous that all of the Morse, starting from the father to Ruth, - everyone's outlook and aspirations were restricted, that they were boring persons, whose speculations were confined to the worldviews, acknowledged by the community. The writer contrasted the literary interior with the spiritual world of heroes, therebycreating a strong psychological parallelism. In the narrow cell, Martin's deliberation and imagination, which has reached a high level of creative and spiritual flight, also collided with the Morse world, who lived in a narrow hollow of their mindset.

\section{RESEARCH METHODOLOGY}

In both novels, there used one more identical psychological style. It is a phenomenon of hero's mental division into two. Such a spiritually complexstate is also observed in the works of Leo Tolstoy's "Resurrection" and Chulpan's "Night and Day". This division in itself reflects two opposite sides of human psychology. One of them is a solicitor and the other is a prosecutor. Having reached a certain level of progress,and after the dispute with his sister, Marian, Martinspeculates about the feature particular both layers of the society: "narrow little lives by narrow little formulas", "failing of being individuals and of really living life because of the childlike formulas by which they were enslaved" (237)At this time, his personality splits into two, and at the present level of spirituality, Martin appears as the "pitifulbeasts" that Martin criticized himself. Current Martin challenges the former Martin: "You were like all the rest, young fellow - Martin sneered. - Your morality and your knowledge were just the same as theirs. You did not think and act for yourself. Your opinions, like your clothes, were ready made; your acts were shaped by popular approval... Well the years have passed, and what do you think about it now?" (237-238). At this very moment there happens a merger between two Martins. Thereby, Martin, whose personality split into two, condemns himself.

\section{DISCUSSION}

In our opinion, in the novel "Mirage" dynamic and typological principles of psychological analysis dominate. That is, Abdulla Kakhkhar shows the mental and psychological state of heroes chiefly by their actions (dynamic principle), and on the other hand, the principle of manifesting the inner world of the character in association to the social and economic aspects of life(typological principle) is also presented. Manifestation of a continuous flow of thoughts, feelings, dialectics (analytical principle) is not common in "Mirage". In general, accordance with the epic image principle in "Mirage" Abdulla Kakhkhar observes the mental states of the heroes from outside.

From the events in the novel we know that Muniskhon falls victim - she shoots herself. This event is presented in short details and barely covers one page. The reader can observe the events that led Muniskhon to suicide from outside. These include: loveless marriage to Mukhtorkhon, marriage of her beloved Saidiy to Sarakhon, rejection of Muniskhon by Saidiy in the nook initiated by her.

The writer mentions the inner spiritual rebellion in Muniskhon, not in the constant flow of thoughts, but in action, event and image. This type of image depicts the principle of an epic form defined by Aristotle - objective, as well as an outward illustration of the reality.

Always remaining proud Muniskhon, never acknowledging openly her love for Saidiy, without long objections marries Mukhtorkhon, who was brutal due to his social status and personality, as if trying to struggle against Saidiy. But for Muniskhon, who thought that after the wedding, she would get used to a loveless marriage, the sound when Mukhtorkhon kissed her reminded of a tweet of a lizard, and his smell of the wooden ladle remaining under the sun. Muniskhon, who goes to the editorial office to search for Saidiy after she heard the news of his wedding with Sorakhon, limply wrinkles her nose to the question: "Did Mukhtorkhon come?", but when Saidiy asked for the reason she wrinkled her nose, she hysterically replies: "No! No! No! My husband is good! The writer does not even speak about her state, tone, when she says the words "No! No! No! My husband is good!", not to mention the presentation of thoughts, feelings experienced by Muniskhon at that moment, but he simply places the responsibility of demonstrating the complex spiritual processes occurring in the bride's soul to the repetition of words and the exclamation mark. Then the situation is described as follows: "Muniskhon was very red, and a thin layer of tears appeared in her pupil gleaming when she turned to leave, Saidiy did not allow her."

As in other works of Abdulla Kakhkhar, in the "Mirage", when revealing the spirituality of the characters in the first place are the dialogue, the speech of the character rather than explanation. The writer does not directly indicate the cause of this tragedy in the novel. In the work it was said about the later life of Saidiy after separation from master Murodkhoja that "the days passed in this way until Muniskhon shot herself for unknown reasons". Nevertheless, the development of events, the psychological circumstances described by the author, indicate that the bullet, which unceremoniously took Muniskhon, mirrors a torment of hopeless love. Even the words 'Like all the rest, Saidiy didn't even know why Muniskhon shot herself," are also very conditional. Because Saidiy knew very well the reason for the death of his beloved - on the one hand, because of the 
conversation in the editorial office and the secluded meeting in a strange house; but, on the other hand, by how he himself experienced the same torments in Muniskhon's soul. The premature death of Muniskhon led to a culmination of spiritual degradation, which was thus deepened with the complete collapse of the dream of social status and writing, ultimately leading to self-destruction. Because, according to the events of the novel, the organization created by the counter-revolutionaries, to which Saidiy strove, was destroyed, as the decline of Saidiy in the sphere of writing not genuinely creating any worthy work he just faded away. But even after that, he finds in himself the hope of living.

When Abdulla Kakhhor wrote that "like all the rest, Saidiy didn't even know why Muniskhon shot herself' he came out from his loyalty to the principle of epic image, which constitutes in describing the hero not from inside, but from the outside. The author of the novel from one angle may seem just a writer, reflecting everything that is happening superficially. He, as it was in some works, does not analyse and judge the internal world of the hero from inside, or deliberate as a hero himself, butappears an outsider observer. "Observing and depicting from outside"- is the basic principle of the epic description. But this does not mean that the author is indifferent to everything that he narrates, that he does not know the spiritual state of the hero or cannot reveal his inner world. In the novel, the observation of the author as a psychologist directly emerge in the situations and details described by him. Simply put, the writer does not attach much importance to all the details and circumstances during a particular event, but describes the details and situations, words that can reveal the emotional state of the hero. The position of the author, his "eye" as a mentalist are presented exactly in this choice. If you look from this point of view, in the novel, and the death of Muniskhon, and the fact that Saidiy knew the reason for this, ultimately that this event entails another tragedy - Saidiy's death was completely psychologically justified.

Another characteristic of Abdulla Kakhkhar, which is outlined in the novel, is that the author takes advantage of single motif of "laughter" for the expression of dozens of mental states. "Laughter is a particular shape of anxiety in the form of self-defence," says Jan Parandovsky. In "Mirage", laughter is also expressed as a sign of different psychological states, not as a sign of joy:

- "How about eating, you fool?" Saidiy said inwardly and laughed. - not to be able to reveal his genuine state due to shame.

- After Kenja repeated his question, Yokubjon replied with a nervous laughter on his face; in master Murodkhoja's face nervous laughter wasreflected; "Even if you are a poet, you are still a tiny sparrow" - said he (master Murodkhoja) laughing with a heap of hardship " - nervousness.

- She did not even tell me what she was up to" - said Saidiy simulating a laughter. - an attempt to prevent tedious conversation.

- Sorakhon pointed at a fly: "Does it walk or fly? Saidiylaughed. "Neither walks, nor flies"-suppressing an internal fuss.
- Saidiy left putting down the ladle. On the way he met a "haranguer". - Well, what happened? Saidiy laughed. "He says he is hungry!" - Laughing at someone's situation, disdain.

\section{CONCLUSION}

As it turns out, Abdulla Kakhkhor was able to show skilfully that a laughter can be a sign of various psychological states. In general, for Abdulla Kakhkhor "speaking details" are common. For example, having received a confirmation letter on his works from the editorial office, Saidiy puts this letter somewhere visible on the day Muniskhon came. "But seeing the letter Muniskhon neglectfully dropped it back to its place, took dried milk into her mouth and opened the book." Here, a little detail about "took dried milk into her mouth " reflects even more clearly the self-assuredness of Muniskhon rather than multi-paged explanations.

Although the novels "Martin Eden" and "Mirage" resemble in the plot events and some other aspects, they differ when it comes to the perspective of the writer's choice of the means of psychological analysis.

\section{REFERENCES}

1.Badanova I. Jack London and his hero. Джек Лондон и его герой Творчество Джека Лондона 1900-1910 гг. - Автореф.дисс... канд.филол.наук. - М., 1963. - С. 12

2. Bikov V. Романы Джека Лондона. Автореф.дисс. ...канд.филол.наук M., 1966. -19 c.

3. Shodiev N. Психологик тахлил принциплари, форма ва воситалари // Ўзбек тили ва адабиёти, 1978 йил, 2-сон. - 3-б.

4. Yuldashev N. Проблемы психологического анализа в узбекской прозе (Внутренний монолог в романах А.Кадыри, Айбека, А.Каххара А.Якубова). Автореф.дисс...канд.филол.наук. - М., 1982.

5. Akhmedova Mehrinigor, Baqoyeva Muhabbat. Analysis of "Spirituality" Category and its Structure in the English Language. International Journal of Innovative Technology and Exploring Engineering (IJITEE) ISSN: 2278-3075, Volume-8, Issue-9S3, July 2019

6. Kholikova Nozima Nematilloyevna, Saidov Khayrulla Shavkatovich.Observation and Analysis of the Peculiarities of English and Uzbek Detective Genre (in the Examples of J.H.Chase's Works. International Journal of Innovative Technology and Exploring Engineering (IJITEE) ISSN: 2278-3075, Volume-8, Issue-9S3, July 2019 